\section{Acknowledgments}

We would like to thank Dr N. C. Tan, Senior Consultant Cardiothoracic Surgeon, for doing the thoracotomy. We gratefully acknowledge the help of $\mathrm{Dr} \mathrm{H}$. I. Tong and $\mathrm{Dr}$ H. L. Yap of the Neurology Unit for doing the EMG and nerve conduction studies. We are indebted to Dr I. W. B. Grant, of Northern General Hospital, Edinburgh, for providing the $\mathrm{K}$ veim antigen.

\section{References}

ChaPMan, J.S. (1955) Note on the secondary factors involved in the etiology of sarcoidosis. American Review of Tuberculosis, 71, 459.
Colover, J. (1948) Sarcoidosis with involvement of the nervous system. Brain, 71, 451.

DA Costa, J.L. (1973) Geographic epidemiology of sarcoidosis in South East Asia. American Review of Respiratory Disease, 108, 1269.

Hsing, C.T. (1964) Sarcoidosis among Chinese. American Review of Respiratory Disease, 89, 917.

KHoo, O.T. \& TANG, K.Y. (1964) Rarity of sarcoidosis in Malaysia. Singapore Medical Journal, 5, 115.

MazzA, G. (1908) Über das multiple benigne Sarkoid der Haut (Boeck). Archiv für Dermatologie und Syphilis, 91, 57.

Snelling, M.R.J. (1966) Pulmonary sarcoidosis. Singapore Medical Journal, 7, 240.

Postgraduate Medical Journal (April 1975) 51, 260-264.

\title{
Behçet's disease and the alimentary tract
}

\author{
J. V. PARKIN* \\ M.B., Ch.B., F.R.C.S. \\ D. G. D. WIGHT \\ M.A., M.B., M.R.C.Path.
}

\section{Addenbrooke's Hospital, Cambridge}

\section{Summary}

Two patients with perforation of the alimentary tract in Behçet's disease are described. One of these is believed to be the first recorded case of oesophageal perforation in this condition, while the second is one of the few survivors of bowel perforation. The literature, aetiology and treatment are reviewed.

THE association of inflammatory disease of the eye with oral aphthous ulceration was first reported by Adamantiades in 1931. Behçet $(1937,1938)$ extended the description to include genital ulceration, and this group of symptoms was generally known as Behçet's syndrome, or Behçet's triple symptom complex. During the 1950s the association of Behçet's syndrome with neurological disease became recognized (Alemà and Magni, 1952; Hermann, 1953; Viane, 1957; Alemà and Bignani, 1966), and polymorphous skin manifestations are well known (Marchionini and Muller, 1966; Nazzaro, 1966). Berlin (1960) emphasized the view of Behçet's disease as 'a multiple symptom complex'. The most extensive and numerous recent reports have come from Japan where the disease is remarkably common (Oshima et al., 1962, 1963; Shimizu, 1970, 1971), yet reported cases of alimentary perforation remain rare. The following case reports include one of oesophageal perforation, believed to be the first on record.

* Present address: Department of Surgical Studies, The Middlesex Hospital, London W1N 8AA.

\section{Case 1}

A 52-year-old housewife first presented in July 1960 with a 3-month history of mouth ulceration, itching eyes and lesions on both arms and legs resembling erythema nodosum. She was treated with Neocortef eye drops and oral prednisone for 3 months. In August she had indigestion, and a barium meal demonstrated an ulcer on the lesser curve of the stomach.

She was then well until June 1961 when there was a recurrence of mouth ulceration, episcleritis and erythema nodosum followed by jaundice. The latter was considered to be due to ascending cholangitis and rapidly settled on antibiotics. Over the next 3 years she had repeated episodes of abdominal pain, sometimes accompanied by vomiting and diarrhoea. Altogether four barium meal and follow-through examinations were performed; one showed a duodenal ulcer and all showed strikingly coarse jejunal folds with dilatation of the upper jejunum. In September 1964 an exploratory laparotomy showed all viscera other than the small bowel to be normal. Throughout the small bowel, from $12 \mathrm{~cm}$ below the duodeno-jejunal junction to $7.5 \mathrm{~cm}$ above the ileocaecal junction, there were multiple discrete lesions $3-5 \mathrm{~mm}$ in diameter with radiating folds and a thickened edge; it was thought that these were of different ages as some appeared fibrotic, some plum-coloured and some bright red. At one point there appeared to have been a sealed perforation. 
A piece of jejunum measuring $3 \times 4 \mathrm{~cm}$ was excised. This contained a mucosal ulcer $1.5 \mathrm{~cm}$ in diameter. Histological examination showed a deep chronic ulcer with a floor of granulation tissue and replacement of the muscle coat by fibrous tissue. There was evidence of active mucosal regeneration at the margins. No vascular lesions were seen.

No other procedure was undertaken and the abdomen was closed. Recovery from this procedure was uncomplicated and for the next 3 months she was well without treatment.

In January 1965 another admission was necessary because of repeated vomiting and mild fluid depletion. Her condition improved rapidly with intravenous fluid replacement and naso-gastric aspiration; steroids were not given. One week after admission she suddenly collapsed and resuscitation was unsuccessful.

Post-mortem examination was performed. The pharynx and larynx were not ulcerated. There were areas of ulceration in the lower oesophagus, duodenum, jejunum and ileum. All the ulcers were circular, had a raised margin and depressed centre and measured on average $1.0 \mathrm{~cm}$ in diameter. Some were associated with slight serosal thickening. They were most frequent in the upper small intestine. One ulcer near the lower end of the oesophagus had perforated and the left pleural cavity contained 500 $\mathrm{ml}$ of dark fluid. On histological examination, despite a certain amount of autolysis, it was possible to recognize areas of necrosis of the mucosa in ulcers from both the oesophagus and the jejunum. There was also a sparse inflammatory cellular infiltrate but no vascular lesions were seen. In contrast, the stomach and duodenum were normal and not ulcerated. The remaining organs of the body were normal.

\section{Case 2}

A 33-year-old electrician presented with Behçet's disease in 1970, giving a 10-year history of recurrent aphthous mouth ulcers, and having recently developed ulcers on the scrotum and one toe. Over the next year he had repeated crops of mouth ulcers, and developed effusions in both knees and also a nodule resembling erythema nodosum on his left calf. The first suggestion of alimentary tract involvement came a year later with an episode of colicky abdominal pain followed by bloody diarrhoea, but this settled spontaneously and neither barium meal and follow-through nor sigmoidoscopy revealed any abnormality.

Seven months later he was admitted as an emergency with a 1-week history of diarrhoea, vomiting and abdominal pain. The pain had become much more severe on the day of admission. On admission he was moderately fluid-depleted, there was one lesion of erythema nodosum but no mouth or genital ulcers. The abdomen was distended with generalized tenderness and guarding, rebound was present in the lower abdomen and bowel sounds were infrequent. $\mathrm{X}$-rays of the abdomen showed a distended loop of small bowel, no free gas and no gas in the colon. A diagnosis of peritonitis of unknown cause was made.

At laparotomy there was a considerable quantity of fluid free in the pelvis. The distal ileum was reddish and granular with multiple ulcers, many perforated; the ascending colon was abnormal with many ulcers none of which had perforated. All the affected bowel was resected. The cut end of ileum was brought out in the right iliac fossa as a formal ileostomy with eversion and suture of mucosa to the skin, and the transverse colon was brought through the upper end of the main wound and left as a mucous fistula. Following peritoneal toilet the abdomen was closed with drainage.

In spite of a very stormy postoperative course, owing to the degree of sepsis, he made a satisfactory recovery from this procedure. He was persistently anaemic until the sepsis had cleared and he was given a total of 9 units of blood. Since his discharge he has continued to improve and gain weight. A barium follow-through examination and barium enema have not shown evidence of residual alimentary disease. It is hoped that intestinal continuity can be restored in the future. He has never at any stage shown signs or symptoms of eye disease, but he has continued to have episodes of mouth ulceration.

The fixed specimen of resected bowel consisted of $100 \mathrm{~cm}$ of ileum with the caecum and $28 \mathrm{~cm}$ of ascending colon. The loops of small bowel were bound together by fibrinous adhesions. Numerous well defined circular areas, up to $2 \mathrm{~cm}$ in diameter, were visible from the serosal aspect of the unopened small bowel (Fig. 1). Here the bowel wall was reduced to a thin yellow membrane, representing full-thickness necrosis, which was intact in some areas but perforated in others. There were, in addition, a number of smaller partial thickness circular lesions on the mucosal aspect of both the small and large bowel. The intervening mucosa appeared normal.

Histological examination confirmed the presence of sharply defined ulcers of varying degrees of penetration, all apparently of similar chronological age. In a few areas merely the tips of the villi were necrotic but most ulcers had penetrated to the submucosa or further (Fig. 2). The floor of the ulcers was composed of granulation tissue and the walls of some of the small vessels, both arteries and veins, in this situation showed inflammatory changes in all coats with patchy fibrinoid necrosis (Fig. 3). Some capillaries were plugged by fibrin thrombi. Vessels away from the margins of ulcers, including the large mesenteric vessels, showed no abnormality. 


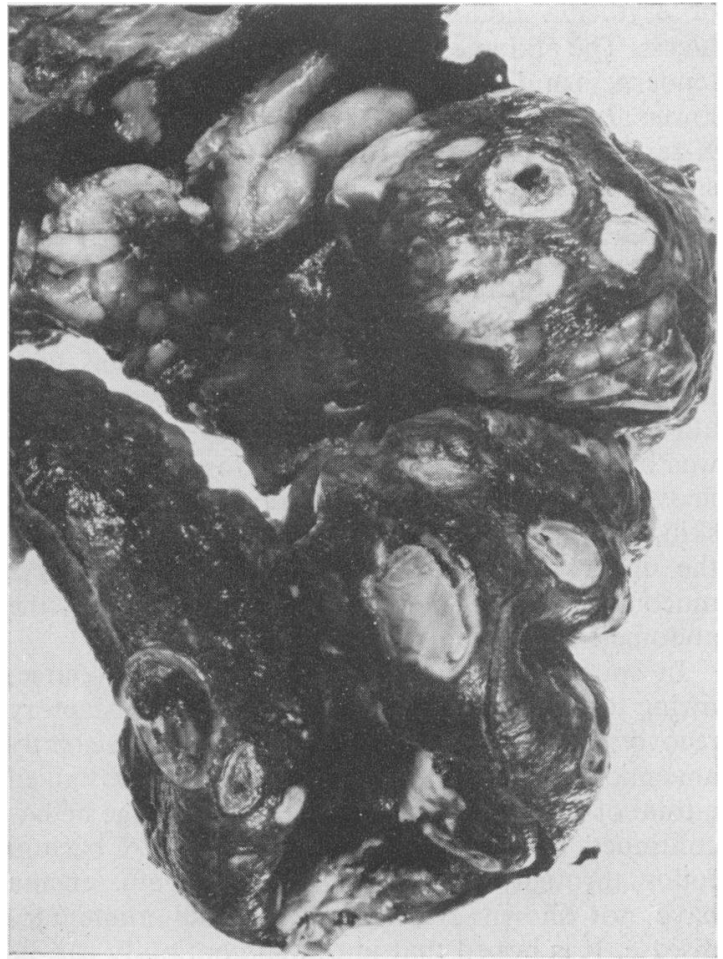

Fig. 1. External appearance of resected specimen from Case 2, showing numerous discrete ulcers.

\section{Discussion}

A form of ulcerative haemorrhagic colitis associated with Behçet's disease was first reported in 1944 by Jensen, and later other forms of alimentary tract involvement were reported (Boe, Delgaard and Scott, 1958; Funasaka, 1958; Ono and Yamamoto, 1962). Nagasu et al. (1961) reported a survivor of acute perforation of the jejunum in Behcet's disease and later Somemura et al. (1963) reported a case with multiple perforations of the distal ileum. Recently there have been further reports (Ramsay, 1967; Menkes, 1970; Courbon and Galmiche, 1971; Empey, 1972) of large bowel involvement. Arma et al. (1971) have reported dysphagia due to oesophageal involvement in Behçet's disease, apparently the first time oesophageal involvement has been described. Oesophageal perforation does not seem to have been reported.

Eye lesions (Billson et al., 1967), skin lesions (Goligher et al., 1968), arthritis and aphthous ulceration (Goligher et al., 1968; Dyer and Sladen, 1972) may occur in both Crohn's disease and ulcerative colitis, so some caution must be exercised in attributing alimentary tract ulceration to Behçet's disease. However, the distribution and morphology of the alimentary lesions described in the present cases are quite distinctive and strongly suggest a vascular aetiology, although the vascular abnormalities were found in only one of the cases.

Theories concerning the aetiology of Behçet's

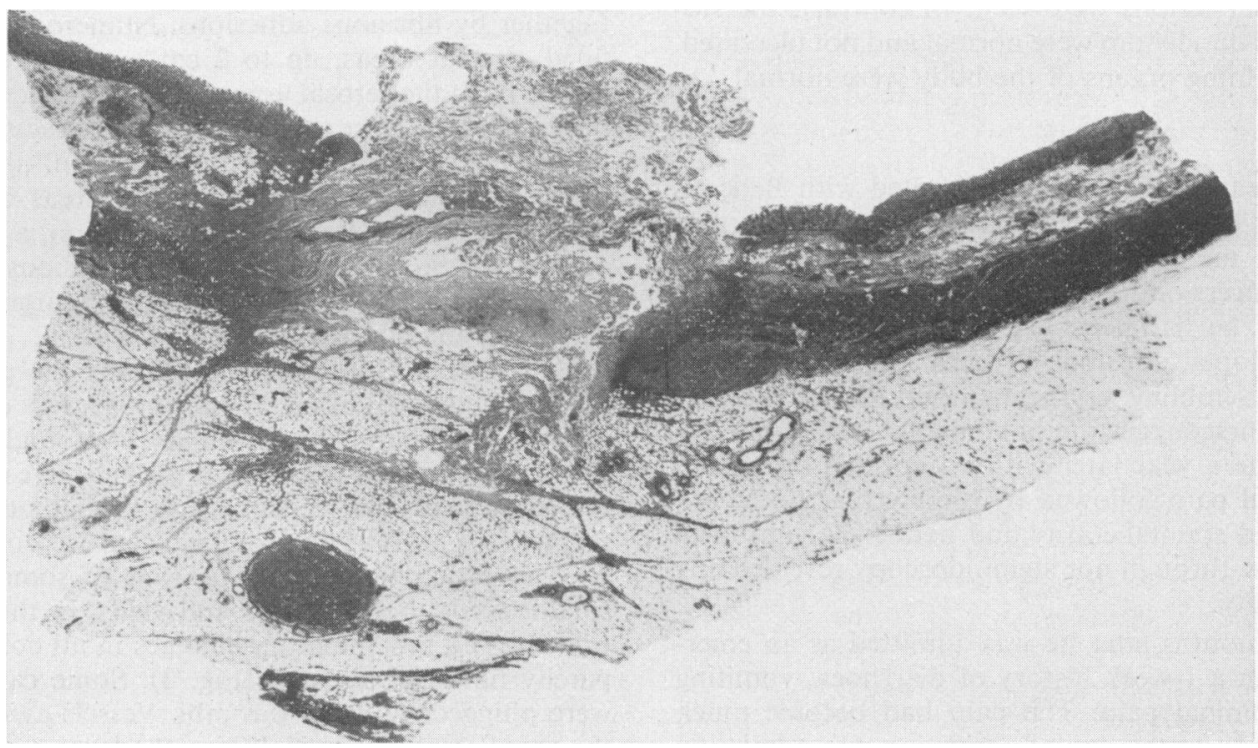

Fig. 2. Section through an ulcer showing full-thickness necrosis of small bowel wall. Case 2 (HE $\times 6)$. 


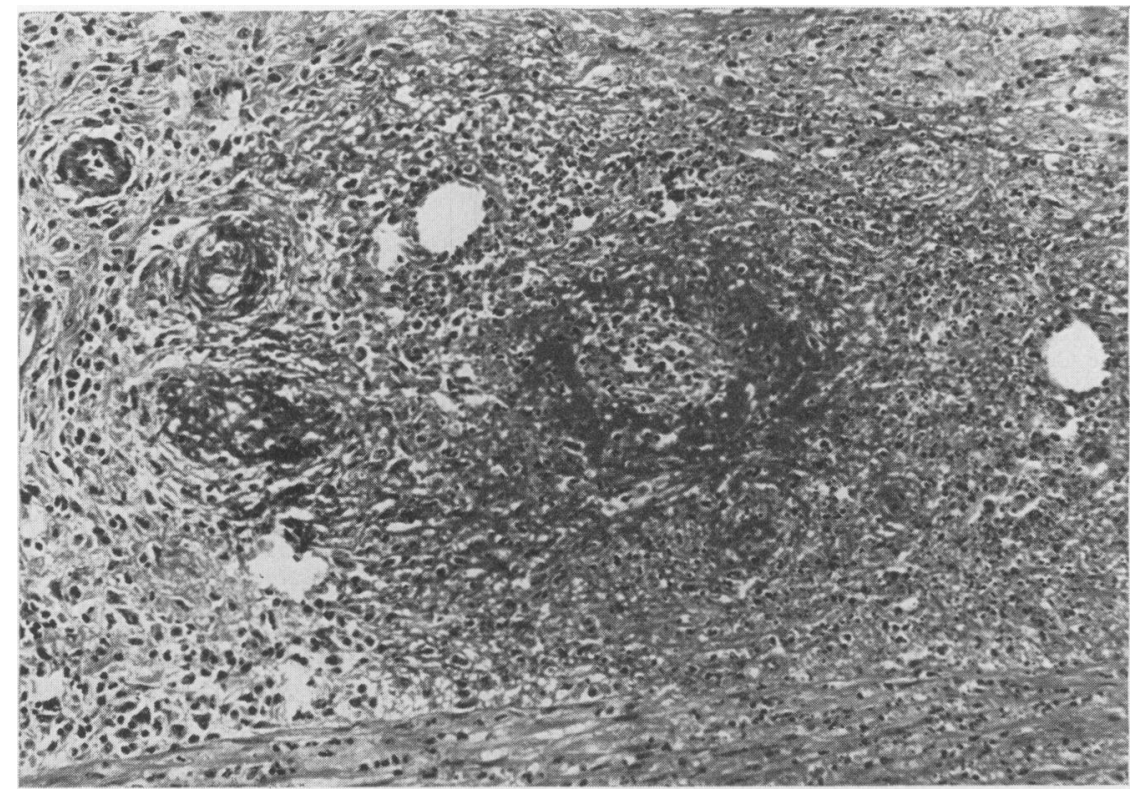

Fig. 3. A small artery from the floor of a shallow ulcer which shows conspicuous fibrinoid necrosis of its wall together with polymorphonuclear leucocytes and nuclear dust, both in the wall and the surrounding submucosa. Case 2 (Picro Mallory $\times 100$ ).

disease have followed the common sequence of parasitic (Behçet, 1938), bacterial (Behçet, 1937), viral (Sezer, 1953) and autoimmune (Shimizu, 1970) theories. Many authors since Behçet have stressed the presence of vascular inflammation which may affect any or all of the coats of the vessel wall. Venules may be affected as frequently as arterioles (Marchionini and Muller, 1966; Nazzaro, 1966). Similar lesions may be produced by such nonspecific stimuli as cutaneous injection of saline (Jensen, 1941 ; Nazzaro, 1966), or by autologous-plasma (Cooper, Penny and Fiddes, 1971). These histological alterations suggest an allergic vasculitis caused by antigen-antibody complexes. Nevertheless, the nature of the antigen involved remains undetermined. The role of antimucosal antibodies is uncertain, since these may be secondary to ulceration, and are detectable in aphthous ulceration with no other stigmata of Behçet's disease (Lehner, 1964, 1967; O'Duffy, Carney and Deodhar, 1971). In contrast, Dolby (1972) has shown no cytotoxic effect of lymphocytes from patients with recurrent aphthous ulceration on colonic mucosal cells.

Various forms of therapy have been favoured for Behçet's disease, in line with the various theories of aetiology. Antibiotic and antiviral therapy have not been shown to alter the natural history of the disease although O'Duffy et al. (1971) report one patient who claimed he could abort or ameliorate oral ulcers by local application of idoxuridine ointment.
Corticosteroids relieve some symptoms but do not affect the overall condition (O'Duffy et al., 1971). Some reports of immunosuppressive therapy have been favourable (Mamo and Azzam, 1970; Rosselet, Saundan and Zenklusen, 1968) while other workers have been less impressed (Wong, 1969). Haim and Sherf (1966) reported a transient favourable response to transfusion of fresh blood or plasma, and O'Duffy et al. (1971) were also impressed by this effect: we did not note any such response to blood transfusion in our patients,'but blood was given only as indicated and no trial of this therapy was undertaken.

At present, the aetiology of Behçet's disease remains unknown, although an allergic vasculitis is most probably a factor. In the absence of knowledge of the aetiology the treatment must be arbitrary, and to a large extent symptomatic. We feel that a firm diagnosis of Behcet's disease involving the alimentary tract can only be made where there is a history of recurrent aphthous ulcers, other manifestations of the systemic disease, and histological examination of affected intestine.

\section{Acknowledgments}

We are grateful to the Department of Medical Illustration, Addenbrooke's Hospital, for the figures. Mr J. M. Smith, Mr W. A. B. Smellie and the late Dr M. J. Greenberg kindly allowed us to report these patients who were under their care. Dr Arthur Rook gave much valuable advice. 


\section{References}

Adamantiades, B. (1931) Sur un cas d'iritis à hypopyon récidivante. Annales d'oculistique, 168, 271.

Alemà, G. \& Bignami, A. (1966) Involvement of the nervous system in Behçet's disease. In: Behçet's Disease (Ed. by M. Monacelli and P. Nazzaro), p. 52. Karger: Basel.

AlemA, G. \& MAGNI, S. (1952) Sulla neuro-Behçet (Morbo di Behçet con meningo-encefalite). Rivista oto-neuro-oftalmologica, 27, 457.

Arma, S., Habibulla, K.S., Price, J.J. \& Leigh Collis, J. (1971) Dysphagia in Behçet's syndrome. Thorax, 26, 155.

BEHÇET, H. (1937) Uber rezidivierende aphthose durch ein Virus verursachte Geschwüre am Mund, am Auge und an den Genitalien. Dermatologische Wochenschrift, 105, 1152.

BEHÇET, H. (1938) Considérations sur les lésions aphtheuses de la bouche et des parties génitales ainsi que sur les manifestations oculaires d'origine probablement parasitaire et observations concernant leur foyer d'infection. Bulletin de la Société française de dermatologie et de syphiligraphie, 45, 420.

BerLin, C. (1960) Behçet's disease as multiple symptom complex. Report of 10 cases. Archives of Dermatology and Syphilology (Chicago), 82, 73.

Billson, F.A., De Dombal, F.T., Watkinson, G. \& GoligHER, J.C. (1967) Ocular complications of ulcerative colitis. Gut, 8, 102.

Boe, J., DelgaARd, J.B. \& Scott, D. (1958) Mucocutaneousocular syndrome with intestinal involvement. American Journal of Medicine, 25, 857.

Cooper, D., Penny, R. \& Fiddes, P. (1971) Autologousplasma sensitisation in Behçet's Disease. Lancet, i, 910.

Courbon, J. \& Galmiche, P. (1971) Syndrome de Behçet et rectocolite hémorragique. Revue du rhumatisme et des maladies ostéo-articulaires, 38, 465.

DolbY, A.E. (1972) The effect of lymphocytes from sufferers from recurrent aphthous ulceration upon colon cells in tissue culture. Gut, 13, 387.

DYer, N.H. \& SLADEN, G.E. (1972) Ulcerative colitis and Crohn's Disease. Medicine, 3, 245.

EMPEY, D.W. (1972) Rectal and colonic ulceration in Behçet's Disease. British Journal of Surgery, 59, 173.

FunASAKA, K. (1958) Gastric juice studies on Behçet's syndrome. Rinshô Ganka (Journal of Clinical Ophthalmology), $12,1601$.

Goligher, J.C., DE Dombal, F.T., Watts, J.McK. \& WATKInSON, G. (1968) Ulcerative colitis. Baillière, Tindall and Cassell: London.

HAIM, S. \& ShERF, K. (1966) Behçet's disease: presentation of 11 cases and evaluation of treatment. Israel Journal of Medical Sciences, 2, 69.

HERMANN, C. JR (1953) Involvement of the nervous system in relapsing uveitis with recurrent genital and oral ulcers (Behçet's syndrome). Archives of Neurology and Psychiatry (Chicago), 69, 399.

JENSEN, T. (1941) Sur les ulcérations aphtheuses de la muqueuse de la bouche et de la peau genitale combinées avec les symptômes oculaires (syndrome de Behçet). Actadermato-venereologica (Stockholm), 22, 176.

JENSEN, T. (1944) Ulcerous haemorrhagic colitis associated with Behçet's Syndrome. Ugeskrift for Lager, 106, 176.
LEHNER, T. (1964) Recurrent aphthous ulceration and autoimmunity. Lancet, ii, 1154.

LEHNER, T. (1967) Stimulation of lymphocyte transformation by tissue homogenates in recurrent oral ulceration. Immunology, 13, 159.

Mamo, J.G. \& Azzam, S.A. (1970) Treatment of Behçet's disease with chlorambucil. Archives of Ophthalmology, 84, 446

Marchionini, A. \& Muller, E. (1966) The Dermatological View of Morbus Hulusi Behçet. In: Behçet's Disease (Ed. by M. Monacelli and P. Nazzaro), p. 6. Karger: Basel.

MENKÈs, C.J. (1970) Behçet's syndroome and haemorrhagic recto-colitis. Revue du rhumatisme et des maladies ostéoarticulaires, 37, 849.

Nagasu, K., Kimura, N., Kukidome, S., Hirama, S., TanaKa, S. \& SaIto, T. (1961) A cured case of Behçet's syndrome with acute perforation of the jejunum. Geka Shinryo (Surgical Diagnosis and Treatment), 3, 679.

Nazzaro, P. (1966) Cutaneous Manifestations of Behçet's Disease. In: Behçet's Disease (Ed. by M. Monacelli and P. Nazzaro), p. 15. Karger: Basel.

O'Duffy, J.D., Carney, J.A. \& Deodhar, S. (1971) Behçet's Disease. Report of 10 cases, 3 with new manifestations. Annals of Internal Medicine, 75, 561.

ONo, M. \& Y амAмOTO, K. (1962) Successfully treated case of Behçet's syndrome with caecal ulcer. Geka (Surgery), 24, 825.

Oshima, Y., Shimizu, T., Yokobari, R., Matsumoto, T., Karino, K., Kagani, T., Nagaya, H. \& Maruyama, R. (1962) Clinical studies of Behçet's syndrome from 100 observed cases. Naika (Journal of Internal Medicine), 9, 701.

Oshima, Y., Shimizu, T., Yokohari, R., Matsumoto, T., Kano, G., Kagami, T. \& Magaya, H. (1963) Clinical studies on Behçet's syndrome. Annals of the Rheumatic Diseases, 22, 36.

RAMSAY, C.A. (1967) Behçet's syndrome with large bowel involvement. Proceedings of the Royal Society of Medicine, 60, 185.

Rosselet, E., Saundan, Y. \& Zenklusen, G. (1968) Les effets de l'azothioprine dans la maladie de Behçet: premiers résultats thérapeutiques. Ophthalmologica, 156, 218.

SEZER, F.N. (1953) The isolation of a virus as the cause of Behçet's disease. American Journal of Ophthalmology, 36, 301.

Shimizu, T. (1970) Behçet's syndrome with special reference to comparison with collagen diseases. Naika (Journal of Internal Medicine), 25, 849.

Shimizu, T. (1971) Epidemiology and the present status of Behçet's syndrome. Saishin igaku (Modern Medicine), 26, 451.

Somemura, S., Nishio, I., Nishida, Y., Hashimoto, K. \& Matsuhara, F. (1963) A case of multiple perforation of distal ileum due to syndrome of Behçet. Geka Shinryo (Surgical Diagnosis and Treatment), 9, 472.

VIANE, A. (1957) La méningo-myélo-encéphalite dans la maladie de Behçet. Acta neurologica et psychiatrica belgica, 57, 599.

WONG, V.G. (1969) Immunosuppressive therapy of ocular inflammatory diseases. Archives of Ophthalmology, 81, 628. 